\title{
Cardiac Physiopathology and Alkaline Phosphatase
}

\author{
Maria João Martins · Isabel Azevedo
}

Published online: 2 December 2008

(C) Springer Science+Business Media, LLC 2008

In their most interesting article [2], Chin et al. describe what seemed to be a surprising finding: abnormally low total alkaline phosphatase activity levels in serum in two children with early-onset protein-losing enteropathy after Fontan operations. Both children had low cardiac output. Increasing the cardiac output resulted in a prompt rise in alkaline phosphatase. A similar observation was reported in two other Fontan patients, but they did not have protein-losing enteropathy. The authors conclude that total serum alkaline phosphatase activity may be a marker of low cardiac output, and attribute the marked oscillations in total alkaline phosphatase activity to variations in osteoblastic function, which they assume to be in strict and immediate dependence on cardiac output.

We have just published a series of results on rat heart alkaline phosphatase [7] which suggest a new possibility for interpretation of the Chin et al. data. The rat heart has high alkaline phosphatase activity, mainly tissue-nonspecific but also tissue-specific intestinal alkaline phosphatase type II. Both isoenzymes present myocardial cell localization (striated pattern), reminiscent of the sarcoplasmic reticulum morphology [7]. Some of our previous work on the functional relationship between alkaline phosphatase activity and transmembrane transport activity [1, 3-6] also suggests the possibility of myocardial alkaline phosphatase having a role in the sarcoplasmic reticulum/cytoplasm movements of calcium. Another interesting observation in our rat heart alkaline phosphatase work is the effect of various drugs affecting cardiac tissue, used in the treatment of cardiovascular diseases, on the activity of alkaline phosphatase [7]. Although under normal conditions, in humans, a large proportion of

M. J. Martins $(\bowtie) \cdot$ I. Azevedo

Department of Biochemistry (U38/FCT), Faculty of Medicine of University of Porto, Porto 4200-319, Portugal

e-mail: mmartins@med.up.pt serum alkaline phosphatase activity is of bone origin, the marked and rapid variations in the enzyme in Fontan patients, accompanying cardiac output variations, may encompass a heart alkaline phosphatase contribution. At present, a putative contribution of heart to total serum alkaline phosphatase activity is unknown, but this deserves investigation.

Cross-referencing of Fontan patients' and probably many other heart pathology patients' data on alkaline phosphatase with basic research results on this ubiquitous enzyme may prove to be a useful exercise.

\section{References}

1. Calhau C, Martel F, Soares-da-Silva P, Hipólito-Reis C, Azevedo I (2002) Regulation of [(3)H]MPP(+) transport by phosphorylation/ dephosphorylation pathways in RBE4 cells: role of ecto-alkaline phosphatase. Naunyn Schmiedebergs Arch Pharmacol 365:349-356

2. Chin AJ, Stephens P, Goldmuntz E, Leonard MB (2008) Serum alkaline phosphatase reflects post-Fontan hemodynamics in children. Pediatr Cardiol Aug 7 (Epub ahead of print)

3. Martel F, Keating E, Calhau C, Azevedo I (2002) Uptake of (3)H1-methyl-4-phenylpyridinium $((3) \mathrm{H}-\mathrm{MPP}(+))$ by human intestinal Caco-2 cells is regulated by phosphorylation/dephosphorylation mechanisms. Biochem Pharmacol 63:1565-1573

4. Martel F, Martins MJ, Calhau C, Hipólito-Reis C, Azevedo I (1998) Postnatal development of organic cation transport in the rat liver. Pharmacol Res 37:131-136

5. Martel F, Martins MJ, Hipólito-Reis C, Azevedo I (1996) Inward transport of $\left[{ }^{3} \mathrm{H}\right]-1$-methyl-4-phenylpyridinium in rat isolated hepatocytes: putative involvement of a P-glycoprotein transporter. Br J Pharmacol 119:1519-1524

6. Martins MJ, Negrão MR, Hipólito-Reis C, Azevedo I (2002) Putative involvement of alkaline phosphatase in the modulation of taurocholate uptake by rat isolated hepatocytes. Pharmacologist 44 (Suppl 1):A41 (abstr 31.11)

7. Mota A, Silva P, Neves D, Lemos C, Calhau C, Torres D, Martel F, Fraga H, Ribeiro L, Alçada MNMP, Pinho MJ, Negrão MR, Pedrosa R, Guerreiro S, Guimarães JT, Azevedo I, Martins MJ (2008) Characterization of rat heart alkaline phosphatase isoenzymes and modulation of activity. Braz J Med Biol Res 41:600-609 